\title{
Simultaneous disintegration of outlet glaciers in Porpoise Bay (Wilkes Land), East Antarctica, driven by sea ice break-up
}

\author{
Bertie W. J. Miles, Chris R. Stokes, and Stewart S. R. Jamieson \\ Department of Geography, Durham University, Science Site, South Road, Durham, DH1 3LE, UK \\ Correspondence to: Bertie W. J. Miles (a.w.j.miles@durham.ac.uk)
}

Received: 10 June 2016 - Discussion started: 14 June 2016

Revised: 13 December 2016 - Accepted: 25 January 2017 - Published: 8 February 2017

\begin{abstract}
The floating ice shelves and glacier tongues which fringe the Antarctic continent are important because they help buttress ice flow from the ice sheet interior. Dynamic feedbacks associated with glacier calving have the potential to reduce buttressing and subsequently increase ice flow into the ocean. However, there are few high temporal resolution studies on glacier calving, especially in East Antarctica. Here we use ENVISAT ASAR wide swath mode imagery to investigate monthly glacier terminus change across six marineterminating outlet glaciers in Porpoise Bay $\left(76^{\circ} \mathrm{S}, 128^{\circ} \mathrm{E}\right)$, Wilkes Land (East Antarctica), between November 2002 and March 2012. This reveals a large near-simultaneous calving event in January 2007, resulting in a total of $\sim 2900 \mathrm{~km}^{2}$ of ice being removed from glacier tongues. We also observe the start of a similar large near-simultaneous calving event in March 2016. Our observations suggest that both of these large calving events are driven by the break-up of the multiyear sea ice which usually occupies Porpoise Bay. However, these break-up events appear to have been driven by contrasting mechanisms. We link the 2007 sea ice break-up to atmospheric circulation anomalies in December 2005 weakening the multi-year sea ice through a combination of surface melt and a change in wind direction prior to its eventual breakup in January 2007. In contrast, the 2016 break-up event is linked to the terminus of Holmes (West) Glacier pushing the multi-year sea ice further into the open ocean, making the sea ice more vulnerable to break-up. In the context of predicted future warming and the sensitivity of sea ice to changes in climate, our results highlight the importance of interactions between landfast sea ice and glacier tongue stability in East Antarctica.
\end{abstract}

\section{Introduction}

Iceberg calving is an important process that accounts for around $50 \%$ of total mass loss to the ocean in Antarctica (Depoorter et al., 2013; Rignot et al., 2013). Moreover, dynamic feedbacks associated with retreat and/or thinning of buttressing ice shelves or floating glacier tongues can result in an increased discharge of ice into the ocean (Rott et al., 2002; Rignot et al., 2004; Wuite et al., 2015; Fürst et al., 2016). At present, calving dynamics are only partially understood (Benn et al., 2007; Chapuis and Tetzlaff, 2014) and models struggle to replicate observed calving rates (van der Veen, 2002; Astrom et al., 2014). Therefore, improving our understanding of the mechanisms driving glacier calving and how glacier calving cycles have responded to recent changes in the ocean-climate system is important in the context of future ice-sheet mass balance and sea level.

Calving is a two-stage process that requires both the initial ice fracture and the subsequent transport of the detached iceberg away from the calving front (Bassis and Jacobs, 2013). In Antarctica, major calving events can be broadly classified into two categories: the discrete detachment of large tabular icebergs (e.g. Mertz Glacier tongue: Massom et al., 2015) or the spatially extensive disintegration of floating glacier tongues or ice shelves into numerous smaller icebergs (e.g. Larsen A and B ice shelves; Rott et al., 1996; Scambos et al., 2009). Observations of decadal-scale changes in glacier terminus position in both the Antarctic Peninsula and East Antarctica have suggested that despite some degree of stochasticity, iceberg calving and glacier advance/retreat is likely driven by external climatic forcing (Cook et al., 2005; Miles et al., 2013). However, despite some well-documented ice-shelf collapses (Scambos et al., 2003; Banwell et al., 2013) and major individual calving events (Masson et al., 


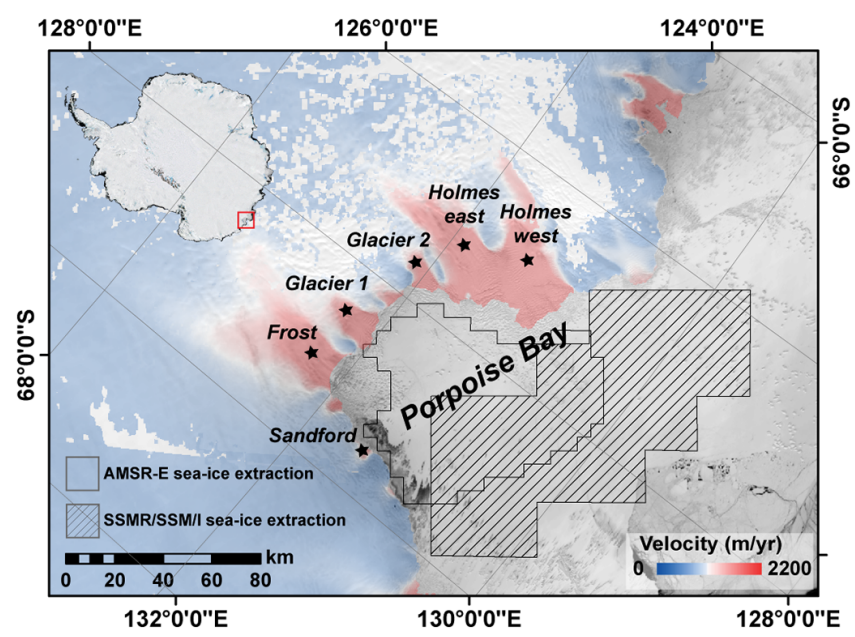

Figure 1. MODIS image of Porpoise Bay, with glacier velocities overlain (Rignot et al., 2011). The hatched polygon represents the region where long-term $25 \mathrm{~km}$ resolution SMMR/SSM/I sea ice concentrations were extracted. The non-hatched polygon represents the region where the higher resolution $(6.25 \mathrm{~km})$ AMSR-E sea ice concentrations were extracted.

2015) there is a paucity of data on the nature and timing of calving from glaciers in Antarctica (e.g. compared to Greenland: Moon and Joughin, 2008; Carr et al., 2013), and particularly in East Antarctica.

Following recent work that highlighted the potential vulnerability of the East Antarctic Ice Sheet in Wilkes Land to ocean-climate forcing and marine ice-sheet instability (Greenbaum et al., 2015; Aitken et al., 2016; Miles et al., 2013, 2016), we analyse the recent calving activity of six outlet glaciers in the Porpoise Bay region using monthly satellite imagery between November 2002 and March 2012. In addition, we also observe the start of a large calving event in 2016. We then turn our attention to investigating the drivers behind the observed calving dynamics.

\section{Study area}

Porpoise Bay $\left(76^{\circ} \mathrm{S}, 128^{\circ} \mathrm{E}\right)$ is situated in Wilkes Land, East Antarctica, approximately $300 \mathrm{~km}$ east of Moscow University Ice Shelf and $550 \mathrm{~km}$ east of Totten Glacier (Fig. 1). This area was selected for study because it occupies a central position in Wilkes Land, which is thought to have experienced mass loss over the past decade (King et al., 2012; Sasgen et al., 2013; McMillan et al., 2014), and which is the only region of East Antarctica where the majority of marineterminating outlet glaciers have experienced recent (20002012) retreat (Miles et al., 2016). This is particularly concerning because Wilkes Land overlies the Aurora Subglacial Basin and, due to its reverse bed slope and deep troughs (Young et al., 2011), it may have been susceptible to unstable grounding line retreat in the past (Cook et al., 2014), and could make significant contributions to global sea level in the future (DeConto and Pollard, 2016). However, despite some analysis on glacier terminus position on decadal timescales (Frezzotti and Polizzi, 2002; Miles et al., 2013, 2016), there has yet to be any investigation of inter-annual and sub-annual changes in terminus position and calving activity in the region.

Porpoise Bay is $150 \mathrm{~km}$ wide and is typically filled with landfast multi-year sea ice (Fraser et al., 2012). In total, six glaciers were analysed, with glacier velocities (from Rignot et al., 2011) ranging from $\sim 440 \mathrm{~m} \mathrm{yr}^{-1}$ (Sandford Glacier) to $\sim 2000 \mathrm{~m} \mathrm{yr}^{-1}$ (Frost Glacier). Recent studies have suggested that the largest (by width) glacier feeding into the bay - Holmes Glacier - has been thinning over the past decade (Pritchard et al., 2009; McMillan et al., 2014).

\section{Methods}

\subsection{Satellite imagery and terminus position change}

Glacier terminus positions were mapped at approximately monthly intervals between November 2002 and March 2012, using Envisat Advanced Synthetic Aperture Radar (ASAR) Wide Swath Mode (WSM) imagery across six glaciers, which were identified from the Rignot et al. (2011) icevelocity data set (Fig. 1). Additional sub-monthly imagery between December 2006 and April 2007 were used to gain a higher temporal resolution following the identification of a major calving event around that time. During the preparation of this manuscript we also observed the start of another large calving event with Sentinel-1 imagery (Table 1).

Approximately $65 \%$ of all glacier frontal measurements were made using an automated mapping method. This was achieved by automatically classifying glacier tongues and sea ice into polygons based on their pixel values, with the boundary between the two taken as the terminus position. The threshold between glacial ice and sea ice was calculated automatically based on the image pixel statistics, whereby sea ice appears much darker than the glacial ice. In images where the automated method was unsuccessful, terminus position was mapped manually. The majority of these manual measurements were undertaken in the austral summer (December-February) when automated classification was especially problematic due to the high variability in backscatter on glacier tongues as a result of surface melt. Following the mapping of the glacier termini, length changes were calculated using the box method (Moon and Joughin, 2008). This method calculates the glacier area change between each time step divided by the width of the glacier, to give an estimation of glacier length change. The width of glacier was obtained by a reference box which approximately delineates the sides of the glacier.

Given the nature of the heavily fractured glacier fronts and the moderate resolution of Envisat ASAR WSM imagery 
Table 1. Satellite imagery used in the study

\begin{tabular}{ll}
\hline Satellite & Date of imagery \\
\hline ARGON & October 1963 (Kim et al., 2007) \\
Envisat ASAR WSM & August 2002, November 2002 to March 2012 (monthly) \\
Landsat & January 1973; February 1991 \\
MODIS & January 2001; December/January 2005/2006; March 2016 \\
RADARSAT & September 1997 (Liu and Jezek, 2004) \\
Sentinel-1 & February-July 2016 \\
\hline
\end{tabular}

$(80 \mathrm{~m})$ it was sometimes difficult to establish whether individual or blocks of icebergs were attached to the glacier tongue. As a result, there are errors in precisely determining terminus change on a monthly timescale $(\sim \pm 500 \mathrm{~m})$. However, because our focus is on major calving events, absolute terminus position is less important than the identification of major episodes of calving activity. Indeed, because estimations of terminus position were made at approximately monthly intervals, calving events were easily distinguished because the following month's estimation of terminus position would clearly show the glacier terminus in a retreated position. In addition, each image was also checked visually to make sure no small calving events were missed (i.e. as indicated by the presence of icebergs proximal to the glacier tongue).

\subsection{Sea ice}

Sea ice concentrations in Porpoise Bay were calculated using mean monthly Bootstrap sea ice concentrations derived from the Nimbus-7 satellite and the Defense Meteorological Satellite Program (DMSP) satellites which offers near complete coverage between October 1978 and December 2014 (Comiso, 2014; doi:10.5067/J6JQLS9EJ5HU). To extend the sea ice record, we also use mean monthly Nimbus-5 Electrically Scanning Microwave Radiometer (ESMR) derived sea ice concentrations (Parkinson et al., 2004; https://nsidc.org/ data/docs/daac/nsidc0009_esmr_aice.gd.html), which offer coverage between December 1972 and March 1977. However, from March to May 1973, August 1973, April 1974, and June to August 1975, mean monthly sea ice concentrations were not available. Sea ice concentrations were extracted from 18 grid cells, covering $11250 \mathrm{~km}^{2}$ across Porpoise Bay, but not into the extended area beyond the limits of the bay (Fig. 1). Grid cells which were considered likely to be filled with glacial ice were excluded. Pack-ice concentrations were also extracted from a $250 \times 150 \mathrm{~km}$ polygon adjacent to Porpoise Bay. The data set has a spatial resolution of $25 \mathrm{~km}$ and monthly sea ice concentration anomalies were calculated from the 1972-2016 monthly mean.

Daily sea ice concentrations derived from the ARTIST Sea ice (ASI) algorithm from Advanced Microwave Scanning Radiometer - EOS (AMSR-E) data (Spreen et al., 2008) were used to calculate daily sea ice concentration anomalies during the January 2007 sea ice break-up (http://icdc.zmaw. de/1/daten/cryosphere/seaiceconcentration-asi-amsre.html). This data set was used because it provides a higher spatial resolution $(6.25 \mathrm{~km})$ compared to those available using Bootstrap-derived concentrations $(25 \mathrm{~km})$. This is important because it provides a more accurate representation of when sea ice break-up was initiated and, due to its much higher spatial resolution, it provides data from much closer to the glacier termini (see Fig. 1).

\subsection{RACMO}

We used the Regional Atmospheric Climate Model (RACMO) V2.3 (van Wessem et al., 2014) to simulate daily surface melt fluxes in the study area between 1979 and 2015 at a $27 \mathrm{~km}$ spatial resolution. The melt values were extracted from floating glacier tongues in Porpoise Bay because the model masks out sea ice, equating to seven grid points. The absolute surface melt values are likely to be different on glacial ice, compared to the sea ice, but the relative magnitude of melt is likely to be similar temporally.

\subsection{ERA-Interim}

In the absence of weather stations in the vicinity of Porpoise Bay we use the $0.25^{\circ}$ ERA-Interim reanalysis data set (http://apps.ecmwf.int/datasets/data/interim-full-moda/ levtype $=\mathrm{sfc} /$ ) to calculate mean monthly wind-field and sea-surface temperature (SST) anomalies, with respect to the 1979-2015 monthly mean. Wind-field anomalies were calculated by using the mean monthly $10 \mathrm{~m}$ zonal $(U)$ and meridional $(V)$ wind components. We also used the daily $10 \mathrm{~m}$ zonal $(U)$ and meridional $(V)$ components to simulate wind-field vectors in Porpoise Bay on 11 January 2007 and 19 March 2016 which are the estimated dates of sea ice break-up.

\section{Results}

\subsection{Terminus position change}

Analysis of glacier terminus position change of six glaciers in Porpoise Bay between November 2002 and March 2012 reveals three broad patterns of glacier change (Fig. 2). The 

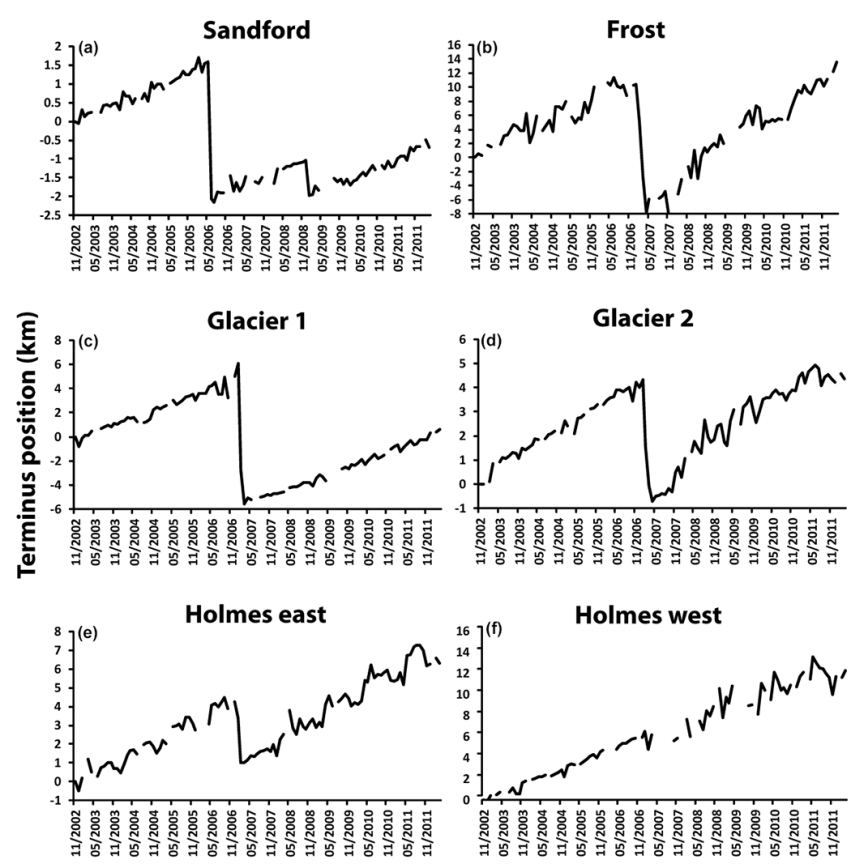

Figure 2. Terminus position change of six glaciers in Porpoise Bay between November 2002 and March 2012. Note the major calving event in January 2007 for five of the glaciers. Terminus position measurements are subject to $\pm 500 \mathrm{~m}$. Note the different scales on $y$ axes.

first pattern is shown by Holmes (West) Glacier, which advances a total of $\sim 13 \mathrm{~km}$ throughout the observation period, with no evidence of any major iceberg calving that resulted in substantial retreat of the terminus beyond the measurement error $( \pm 500 \mathrm{~m})$. The second is shown by Sandford Glacier tongue, which advanced $\sim 1.5 \mathrm{~km}$ into the ocean between November 2002 and April 2006, before its floating tongue broke away in May 2006. A further smaller calving event was observed in January 2009. Overall, by the end of the study period, its terminus had retreated around $1 \mathrm{~km}$ from its position in November 2002. The third pattern is shown by Frost Glacier, Glacier 1, Glacier 2, and Holmes (East) Glaciers, which all advanced between November 2002 and January 2007, albeit with a small calving event in Frost Glacier in May 2006. However, between January and April 2007, Frost Glacier, Glacier 1, Glacier 2, and Holmes (East) Glaciers all underwent a large near-simultaneous calving event. This led to $1300 \mathrm{~km}^{2}$ of ice being removed from glaciers in Porpoise Bay, although we also note the disintegration of a major tongue from an unnamed glacier further west, which contributed a further $1600 \mathrm{~km}^{2}$. Thus, in a little over three months, a total of $2900 \mathrm{~km}^{2}$ of ice was removed from glacier tongues in the study area (Fig. 3). Following this calving event, the fronts of these glaciers stabilized and began advancing at a steady rate until the end of the study period (March 2012) (Fig. 2), with the exception of Frost Glacier which underwent a small calving event in April 2010.
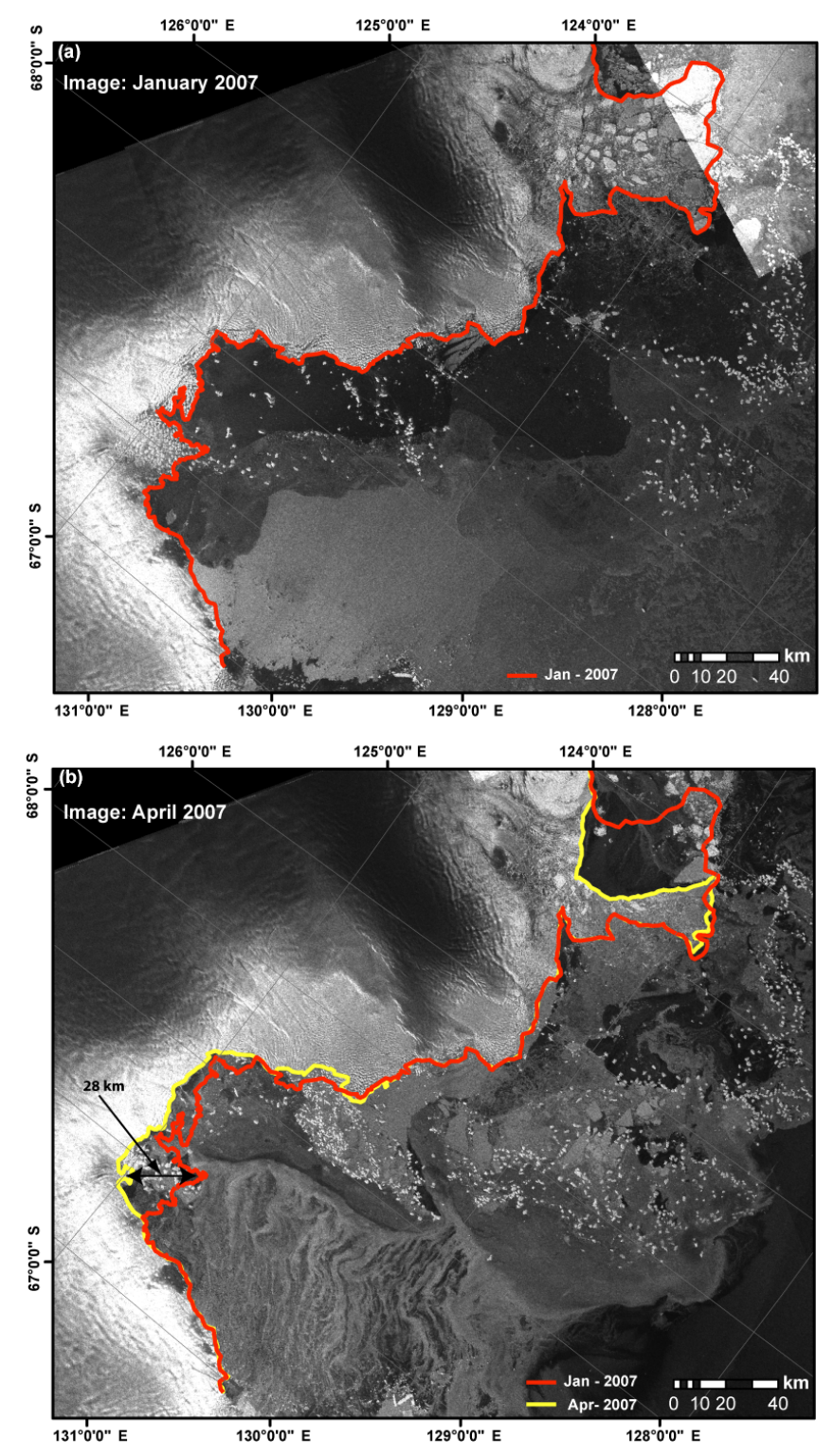

Figure 3. Envisat ASAR WSM imagery in January 2007 (a) and April 2007 (b), which are immediately prior to and after a nearsimultaneous calving event in Porpoise Bay. Red line shows terminus positions in January 2007 and yellow line shows the positions in April 2007.

\subsection{Evolution of the 2007 calving event}

A series of eight sub-monthly images between 11 December 2006 and 8 April 2007 shows the evolution of the 2007 calving event (Fig. 4). Between 11 December 2006 and 2 January 2007, the landfast sea ice edge retreats past Sandford Glacier to the edge of Frost Glacier and there is some evidence of sea ice fracturing in front of the terminus of Glacier 2 (Fig. 4b). From 2 to 9 January a small section $\left(\sim 40 \mathrm{~km}^{2}\right)$ of calved ice broke away from Frost Glacier, approximately in line with the retreat edge of landfast sea ice 

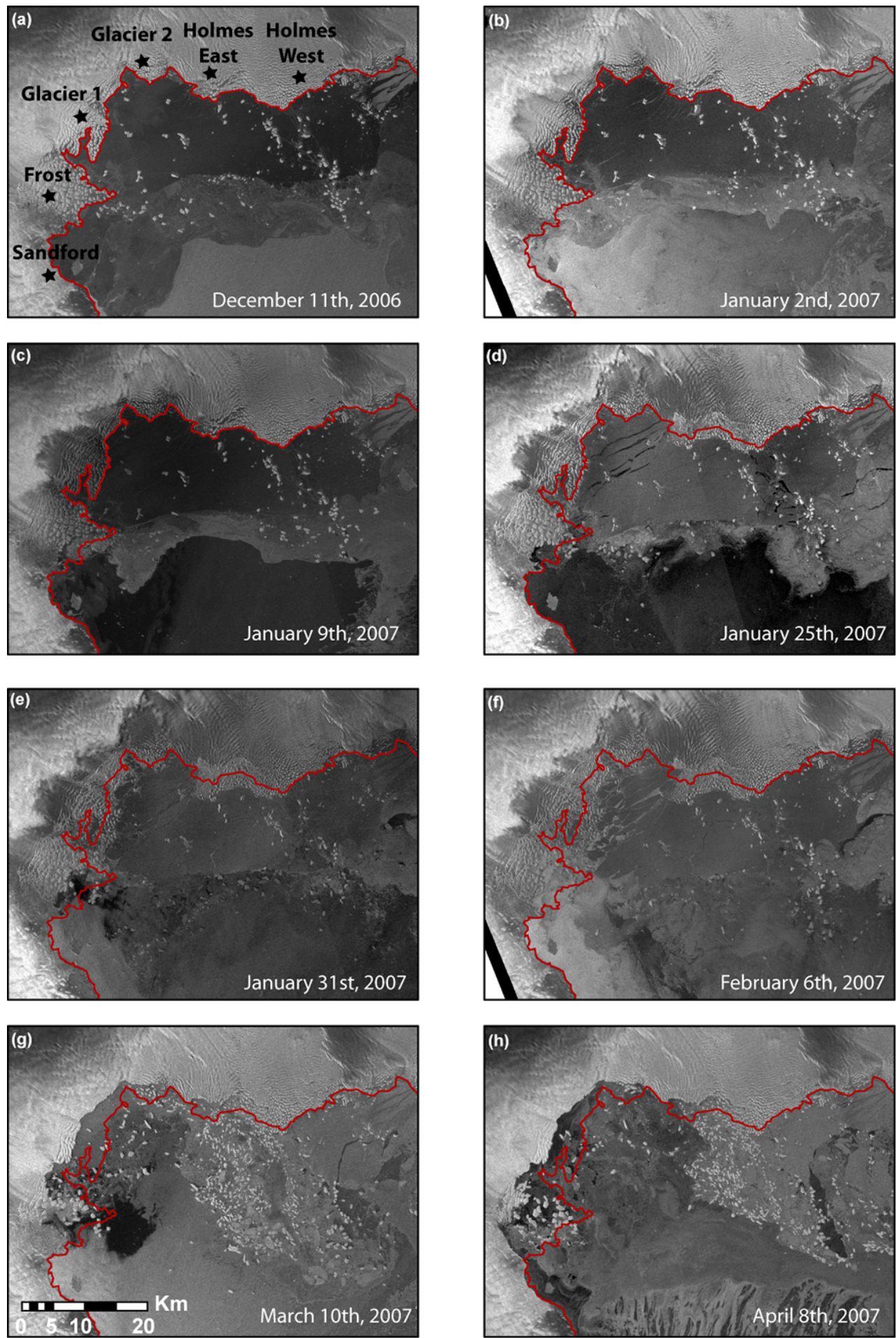

Figure 4. Envisat ASAR WSM imagery showing the evolution of the 2007 calving event. Red line shows the terminus positions from 11 December 2006 on all panels. 
(Fig. 4c). By 25 January, significant fracturing in the landfast sea ice had developed, and detached icebergs from Frost, Glaciers 1, Glacier 2, and Holmes (East) Glaciers begin to breakaway (Fig. 4d). This process of rapid sea ice breakup in the east section of the bay and the disintegration of sections of Frost Glacier, Glacier 1, Glacier 2 and Holmes (East) Glaciers continues up to 10 March 2007 (Fig. 4g). In contrast, the west section of Porpoise Bay remains covered in sea ice in front of Holmes (West) Glacier, which does not calve throughout this event. By 8 April, the calving event had ended with a large number of calved icebergs now occupying the bay (Fig. 4h).

\subsection{6 calving event}

During the preparation of this manuscript satellite observations of Porpoise Bay revealed that another large nearsimultaneous disintegration of glacier tongues in Porpoise Bay was currently underway. This event was initiated on 19 March where the edge of the multi-year sea ice retreated to the Holmes (West) Glacier terminus, removing multi-year sea ice which was at least 14 years old. By 24 March this had led to the rapid disintegration of an $800 \mathrm{~km}^{2}$ section of the Holmes (West) Glacier tongue (Fig. 5). This was the first observed calving of Holmes (West) Glacier at any stage between November 2002 and March 2016. Throughout March and April the break-up of sea ice continued and by 13 May it had propagated to the terminus of Frost Glacier, resulting in the disintegration of a large section of its tongue (Fig. 6). By 24 July sea ice had been removed from all glacier termini in Porpoise Bay at some point during the event, resulting in a total of $\sim 2200 \mathrm{~km}^{2}$ ice being removed from glacier tongues (Fig. 6).

\subsection{The link between sea ice and calving in Porpoise Bay}

Analysis of mean monthly sea ice concentration anomalies in Porpoise Bay between November 2002 and June 2016 (Fig. 7) reveals that a major negative sea ice anomaly occurred between January and June 2007, where monthly sea ice concentrations were between 35 and $40 \%$ below average. This is the only noticeable ( $>20 \%$ ) negative ice anomaly in Porpoise Bay and it coincides with the major January 2007 calving event (see Fig. 4). However, despite satellite imagery showing the break-up of sea ice prior to the 2016 calving event (Figs. 5 and 6), in a similar manner to that in 2007 (e.g. Fig. 4), no large negative anomaly is present in the sea ice concentration data. This is likely to reflect the production of a large armada of icebergs following the disintegration of Holmes (West) Glacier (e.g. Fig. 6), helping to promote a rapid sea ice reformation in the vicinity of Porpoise Bay. Furthermore, we note that the smaller calving events of Sandford and Frost glaciers all take place after sea ice had retreated away from the glacier terminus (Fig. 8). Indeed, throughout
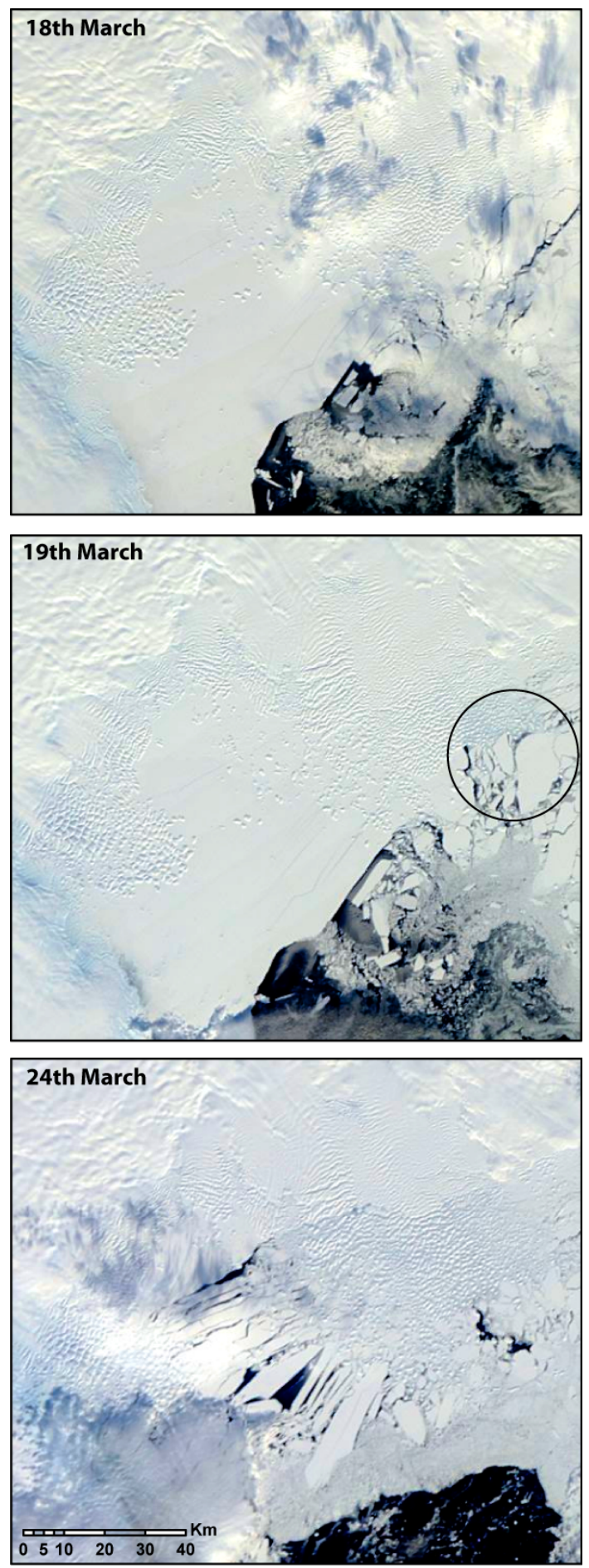

Figure 5. MODIS imagery showing the initial stages of disintegration of Holmes (West) Glacier in March 2016. On 19 March a large section of sea ice breaks away from the terminus (circled), initiating the rapid disintegration process. By 24 March an $800 \mathrm{~km}^{2}$ section of Holmes (West) Glacier tongue had disintegrated. 

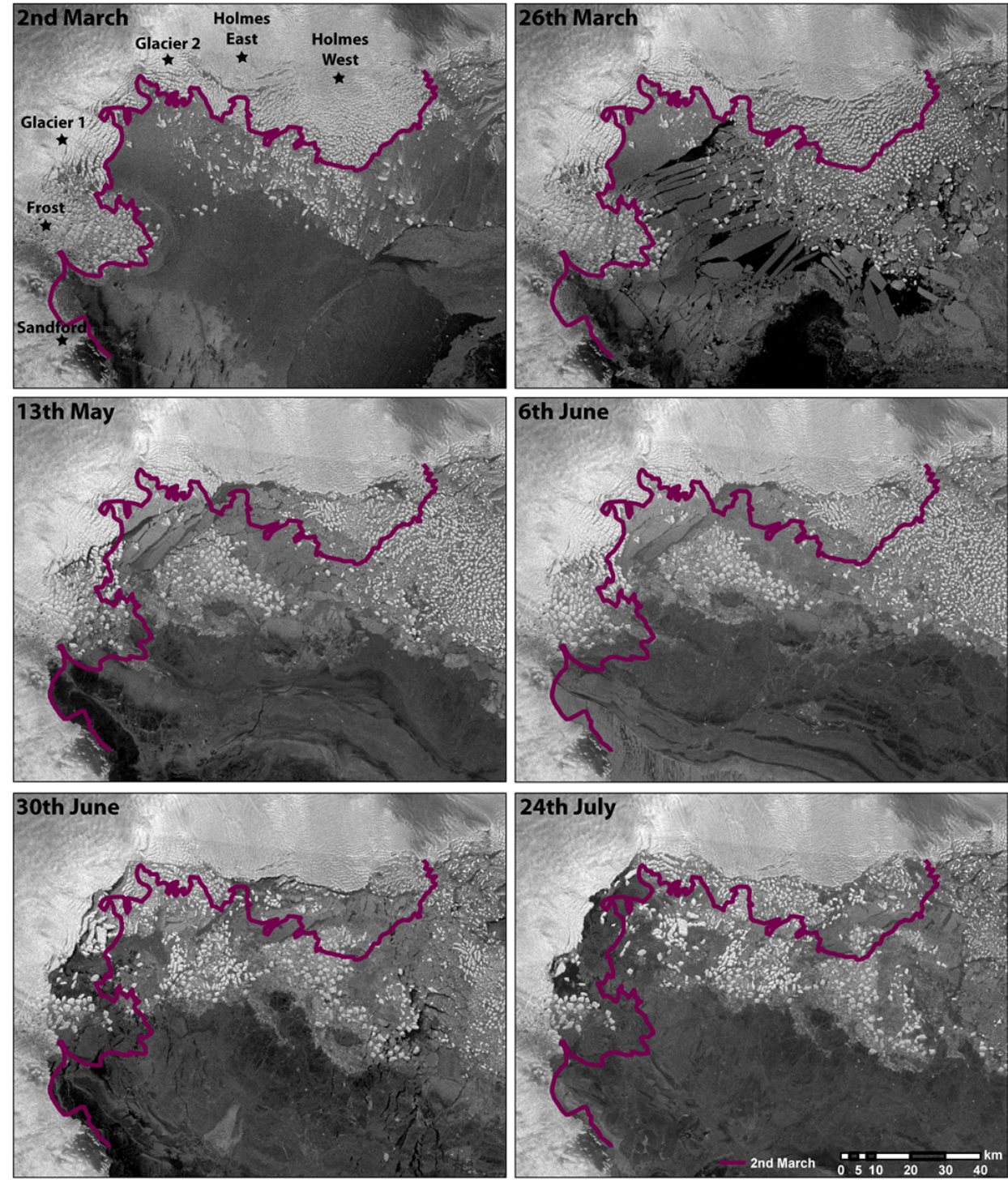

Figure 6. Sentinel-1 imagery showing the evolution of the 2016 calving event. Purple line shows the terminus position from 2 March on all panels.

the study period, there is no evidence of any calving events taking place with sea ice proximal to glacier termini. This suggests that glaciers in Porpoise Bay are very unlikely to calve with sea ice present at their termini.

\subsection{Atmospheric circulation anomalies}

Atmospheric circulation anomalies in the months preceding the January 2007 and March 2016 sea ice break-ups reveal contrasting conditions. In the austral summer which preceded the January 2007 break-up there were strong positive SST anomalies and atmospheric-circulation anomalies throughout December 2005 (Fig. 9a). The circulation anomaly was reflected in a strong easterly airflow offshore from Porpoise Bay. This is associated with a band of cooler
SSTs close to the coastline and the northward shift of the Antarctic Coastal Current in response to the weakened westerlies (e.g. Langlais et al., 2015). A weakened zonal flow combined with high SST in the South Pacific would allow the advection of warmer maritime air into Porpoise Bay. Consistent with warmer air are estimates of exceptionally high melt values in Porpoise Bay during December 2005 derived from the RACMO2.3, which contrasts with the longer-term trend of cooling (Fig. 10). However, the December 2005 anomaly was short lived and, by January 2006, the wind-field conditions were close to average, although SST remained slightly higher than average (Fig. 9b).

In December 2006 and January 2007, which are the months immediately before and during the break-up of sea ice, atmospheric conditions were close to average, with very 


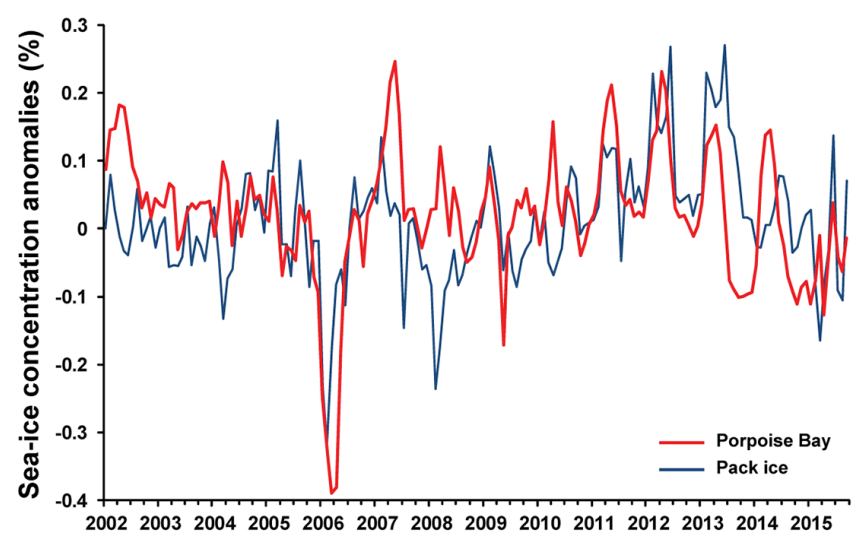

Figure 7. Mean monthly sea ice concentration anomalies from November 2002 to June 2016. The red line indicates sea ice concentration anomalies in Porpoise Bay and the blue line indicates pack-ice-concentration anomalies.

little deviation from mean conditions in the wind field and a small negative SST anomaly (Fig. 9c). However, on 11 January 2007 , which is the estimated date of sea ice break-up from AMSR-E data, we note that there were very high winds close to Porpoise Bay (Fig. 11a).

In contrast to the months preceding the January 2007 event, we find little deviation from average conditions prior to the March 2016 break-up event. In the austral summer which preceded the 2016 break-up (2014/2015), there was little deviation from the average wind field and only a small increase from average SSTs (Fig. 9d). In December and January 2015/2016, there was evidence for a small increase in the strength of westerly winds, and cooler SSTs in the South Pacific (Fig. 9e). However, in February and March 2016 there was no change from the average wind field and slightly cooler SSTs (Fig. 9f).We note, however, that there was a low-pressure system passing across Porpoise Bay on 19 March 2016, the estimated date of break-up initiation (Fig. 11b).

\subsection{Holmes (West) Glacier calving cycle}

Through mapping the terminus position in all available satellite imagery (Table 1) dating back to 1963, we are able to reconstruct large calving events on the largest glacier in Porpoise Bay, Holmes (West) (Fig. 12). On the basis that a large calving event is likely during the largest sea ice break-up events, we estimate the date of calving based on sea ice concentrations in Porpoise Bay when satellite imagery is not available. Our estimates suggest that Holmes (West) Glacier calves at approximately the same position in each calving cycle, including the most recent calving event in March 2016.
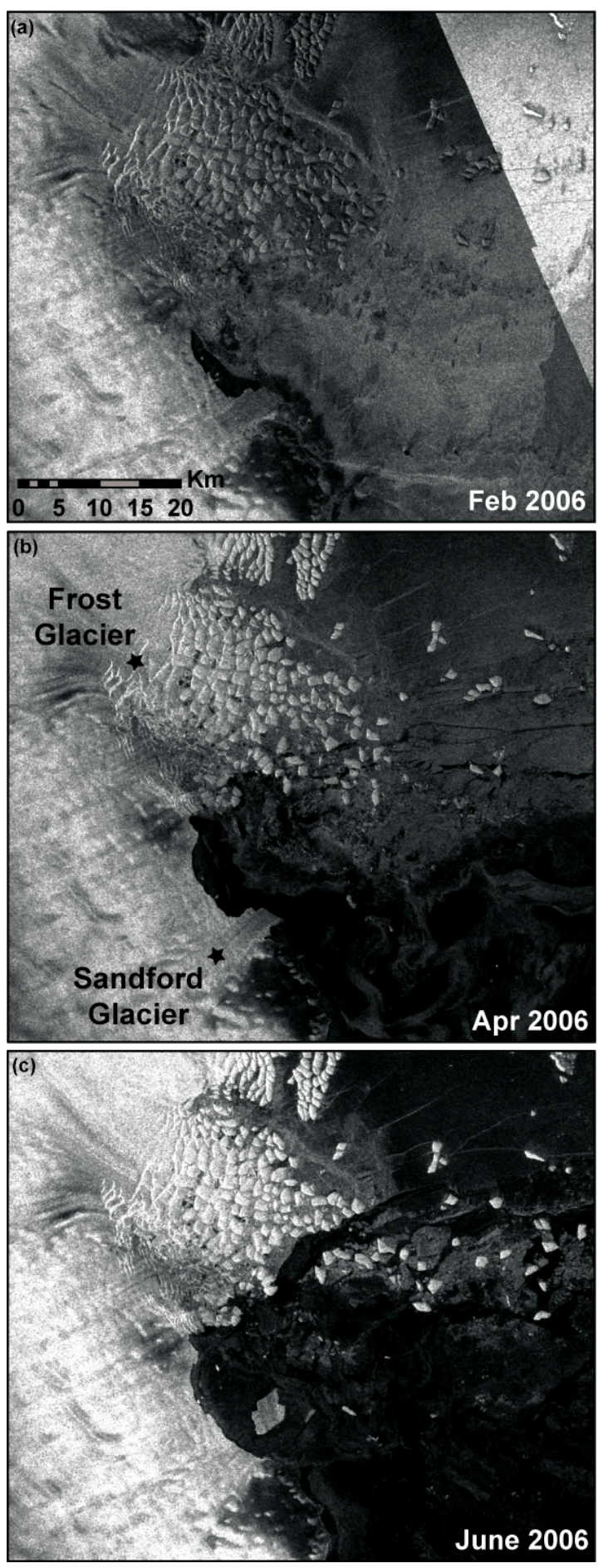

Figure 8. Time series of Frost and Sandford glaciers calving showing that sea ice clears prior to calving and dispersal of icebergs. 

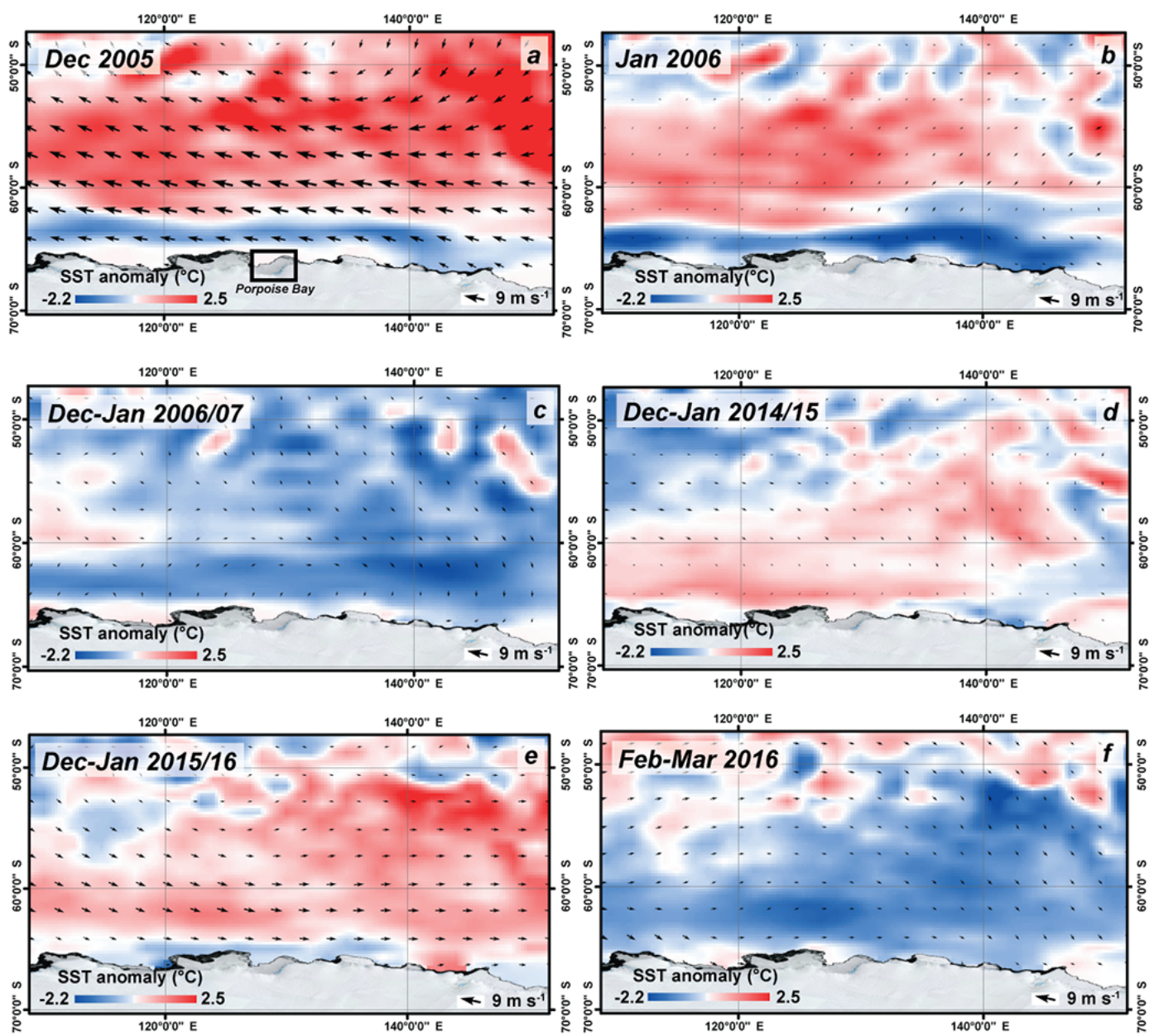

Figure 9. Mean monthly ERA-Interim derived wind-field and sea-surface temperature anomalies in the months preceding the 2007 and 2016 sea ice break-ups: (a) December 2005, (b) January 2006, (c) mean December and January 2006/2007, (d) mean December and January 2014/2015, (e) mean December and January 2015/2016, and (f) mean February and March 2016.

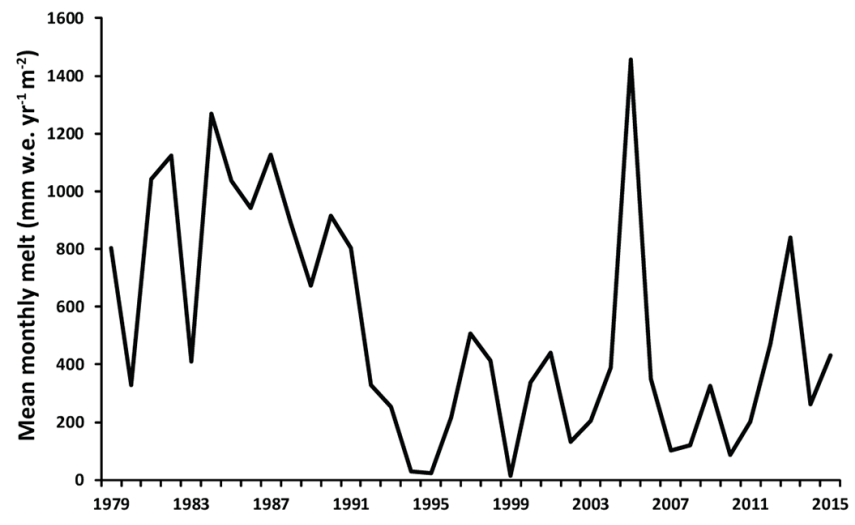

Figure 10. Mean RACMO2.3-derived December melt 1979-2015 in Porpoise Bay.

\section{Discussion}

\subsection{Sea ice break-up and the disintegration of glacier tongues in Porpoise Bay}

We report a major, near-synchronous calving event in January 2007 and a similar event that was initiated in 2016. This resulted in $\sim 2900$ and $2200 \mathrm{~km}^{2}$ of ice respectively, being removed from glacier tongues in the Porpoise Bay region of East Antarctica. These calving events are comparable to some of the largest disintegration events ever observed in Antarctica (e.g. Larsen A in 1995, $4200 \mathrm{~km}^{2}$ and Larsen B in $2002,3250 \mathrm{~km}^{2}$ ); and is the largest event to have been observed in East Antarctica. However, they differ from those observed on the ice shelves of the Antarctic Peninsula, in that they may be more closely linked to a cycle of glacier advance and retreat, as opposed to a catastrophic collapse that may be unprecedented. 


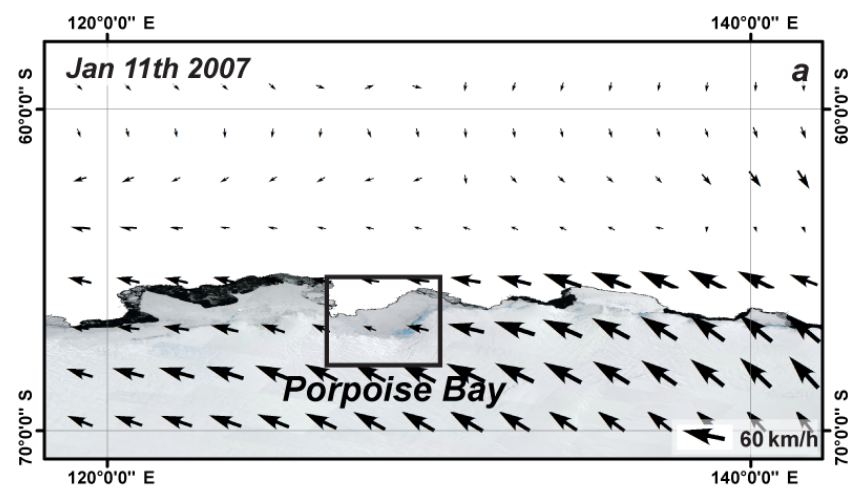

$120^{\circ} 0^{\prime} 0^{\prime \prime} \mathrm{E}$

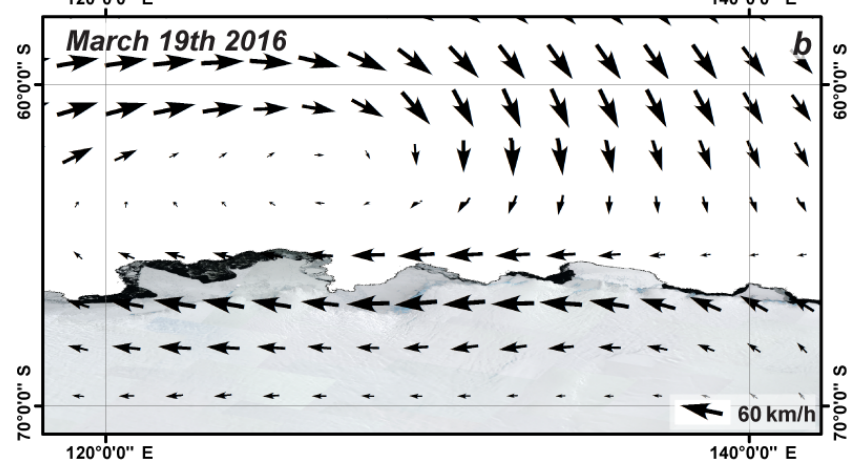

Figure 11. ERA-Interim derived wind fields for the estimated dates of sea ice break-up. (a) 11 January 2007 and (b) 19 March 2016.

Given the correspondence between the sea ice and glacierterminus changes, we suggest that these disintegration events were driven by the break-up of the multi-year landfast sea ice which usually occupies Porpoise Bay and the subsequent loss of buttressing of the glacier termini. A somewhat similar mechanism has been widely documented in Greenland, where the dynamics of sea ice melange in proglacial fjords have been linked to inter-annual variations in glacier terminus position (Amundson et al., 2010; Carr et al., 2013; Todd and Christoffersen, 2014; Cassotto et al., 2015). Additionally, the mechanical coupling between thick multi-year landfast sea ice and glacier tongues may have acted to stabilize and delay the calving of the Mertz Glacier tongue (Massom et al., 2010) and Brunt/Stancomb-Wills Ice Shelf system (Khazendar et al., 2009). However, this is the first observational evidence directly linking multi-year landfast sea ice break-up to the large-scale and rapid disintegration of glacier tongues. This is important because landfast sea ice is highly sensitive to climate (Heil, 2006; Mahoney et al., 2007) and, if future changes in climate were to result in a change to the persistence and/or stability of the landfast ice in Porpoise Bay, it may result in detrimental effects on glacier tongue stability. An important question, therefore, is: what process(es) cause sea ice break-up?

\subsection{What caused the January 2007 and March 2016 sea ice break-ups?}

The majority of sea ice in Porpoise Bay is multi-year sea ice (Fraser et al., 2012), and it is likely that various climatic processes operating over different timescales contributed to the January 2007 sea ice break-up event. Although there are no long-term observations of multi-year sea ice thickness in Porpoise Bay, observations and models of the annual cycle of multi-year sea ice in other regions of East Antarctica suggest that multi-year sea ice thickens seasonally and thins each year (Lei et al., 2010; Sugimoto et al., 2016; Yang et al., 2016). Therefore, the relative strength, stability and thickness of multi-year sea ice over a given period is driven not only by synoptic conditions in the short term (days/weeks), but also by climatic conditions in the preceding years.

In the austral summer (2005/2006) which preceded the break-up event in January 2007, there was a strong easterly airflow anomaly throughout December 2005 directly adjacent to Porpoise Bay (Fig. 9a). This anomaly represents the weakening of the band of westerly winds which encircle Antarctica, and is reflected in an exceptionally negative Southern Annular Mode (SAM) index in December 2005 (Marshall, 2003). This contrasts with the long-term trend for a positive SAM index (Marshall, 2007; Miles et al., 2013). A weaker band of westerly winds combined with anomalously high SST in the southern Pacific (Fig. 9a) would allow a greater advection of warmer maritime air towards Porpoise Bay. Indeed, RACMO2.3-derived surface-melt estimates place December 2005 as the second highest mean melt month (1979-2015) on the modelled output in Porpoise Bay (Fig. 10). To place this month into perspective, we note that it would rank above the average melt values of all Decembers and Januarys since 2000 on the remnants of Larsen B Ice Shelf. Comparing MODIS satellite imagery from before and after December 2005 reveals the development of significant fracturing in the multi-year sea ice (Fig. 13a, b). These same fractures remain visible prior to the break-out event in January 2007 and, when the multi-year sea ice begins to break-up, it ruptures along these pre-existing weaknesses (Fig. 13c). As such, this strongly suggests that the atmospheric-circulation anomalies of December 2005 played an important role in the January 2007 multi-year sea ice break-up and near-simultaneous calving event.

The break-up of landfast sea ice has been linked to dynamic wind events and ocean swell (Heil, 2006; Ushio, 2006; Fraser et al., 2012). Thus, it is possible that the wind anomalies in December 2005 may have been important in initiating the fractures observed in the sea ice in Porpoise Bay, through changing the direction and/or intensity of oceanic swell. However, this mechanism is thought to be at its most potent during anomalously low pack-ice concentrations because pack ice can act as a buffer to any oceanic swell (Langhorne et al., 2001; Heil, 2006; Fraser et al., 2012). That said, we note that pack-ice concentrations offshore from 


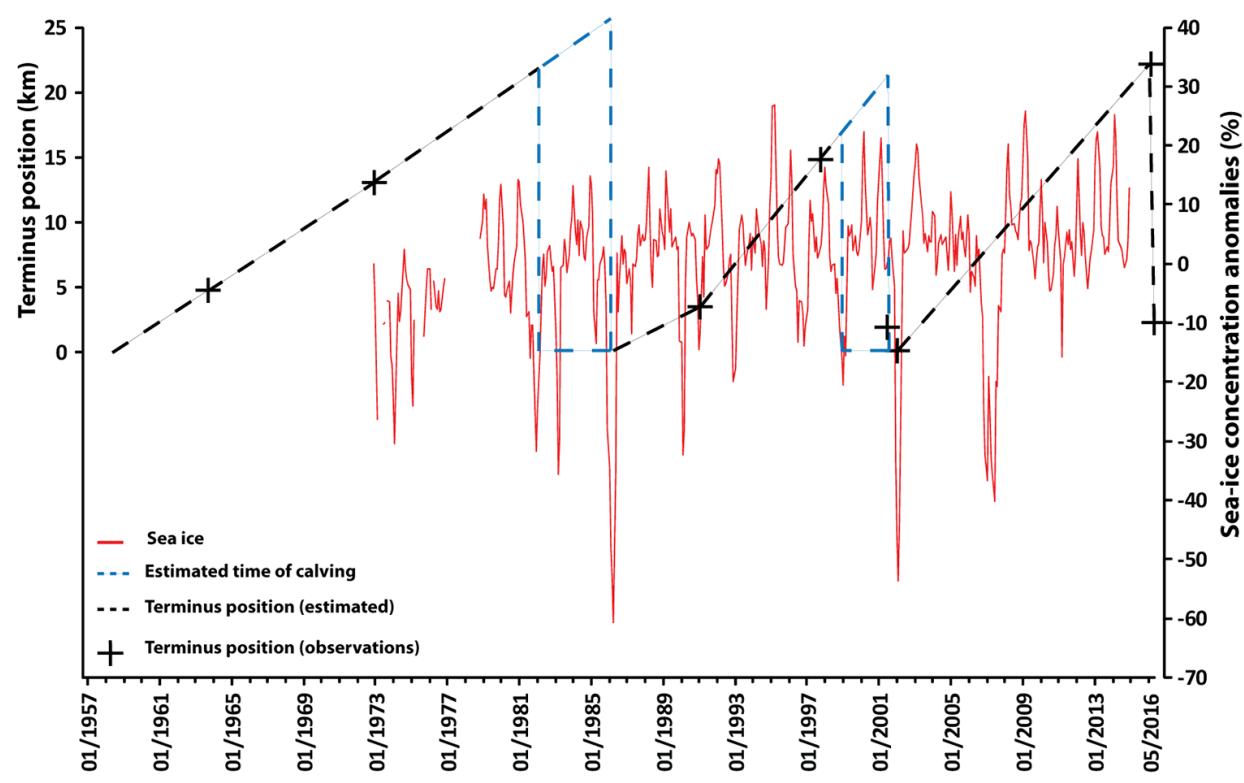

Figure 12. Reconstruction of the calving cycle of Holmes (West) Glacier. All observations are represented by black crosses. The estimated terminus position is then extrapolated linearly between each observation. In periods without observations the date of calving is estimated by negative sea ice concentration anomalies.

Porpoise Bay were around average during December 2005 (Fig. 7). This may suggest that there are other mechanisms that were important in the weakening of the multi-year sea ice in Porpoise Bay in December 2005.

In the Arctic, sea ice melt-ponding along pre-existing weaknesses has been widely reported to precede sea ice break-up (Ehn et al., 2011; Petrich et al., 2012; Landy et al., 2014; Schroder et al., 2014; Arntsen et al., 2015). Despite its importance in the Arctic, it has yet to be considered as a possible factor in landfast sea ice break-up in coastal Antarctica. As a consequence of the high melt throughout December 2005, the growth of sea ice surface ponding would be expected, in addition to surface thinning of the sea ice. Highresolution cloud-free optical satellite coverage of Porpoise Bay throughout December 2005 is limited, but ASTER imagery in the vicinity of Frost Glacier on the 4 and 31 December 2005 shows surface melt features and the development of fractures throughout the month (Fig. 13d, e), similar to those observed elsewhere in East Antarctica (Kingslake et al., 2015; Langley et al., 2016). High-resolution imagery from 16 January 2006 (via Google Earth) shows the development of melt ponds on the sea ice surface (Fig. 13f). Therefore, it is possible that surface melt had some impact on the fracturing of landfast sea ice in Porpoise Bay. This may have caused hydro-fracturing of pre-existing depressions in the landfast ice or surface thinning may have made it more vulnerable to fracturing through ocean swell or internal stresses. Additionally, the subsequent refreezing of some melt ponds may temporally inhibit basal ice growth, potentially weakening the multi-year sea ice and predisposing it to future breakup (Flocco et al., 2015). It is important to note that the atmo- spheric circulation anomalies which favoured the development of fractures in the multi-year sea ice in December 2005 were short-lived. By January 2006, atmospheric conditions had returned close to average (Fig. 9b) and remained so until the austral winter, where sea ice break-up is less likely. This may explain the lag between the onset of sea ice fracturing in December 2005 and its eventual break-up in the following summer (January 2007).

Consistent with the notion that the multi-year sea ice was already in a weakened state prior to its break-up in 2007, is that the break-up occurred in January, several weeks before the likely annual minima in multi-year sea ice thickness (Yang et al., 2016; Lei et al., 2010) and landfast ice extent (Fraser et al., 2012). Additionally, atmospheric circulation anomalies indicate little deviation from average conditions in the immediate months preceding break-up (Fig. 9b, c), suggesting that atmospheric conditions were favourable for sea ice stability. Despite this, a synoptic event is still likely required to force the break-up in January 2007. Daily sea ice concentrations in Porpoise Bay in January 2007 show a sharp decrease in sea ice concentrations after 12 January, representing the onset of sea ice break-out (Fig. 14). This is preceded by a strong melt event recorded by the RACMO2.3 model, centred on 11 January, which may represent a low-pressure system. Indeed, ERA-Interim estimates of the wind field suggest strong southeasterly winds in the vicinity of Porpoise Bay (Fig. 11a). Unlike in December 2005, pack-ice concentrations offshore of Porpoise Bay were anomalously low (Fig. 7). Therefore, with less pack-ice buttressing, it is possible that the melt event, high winds, and associated ocean 

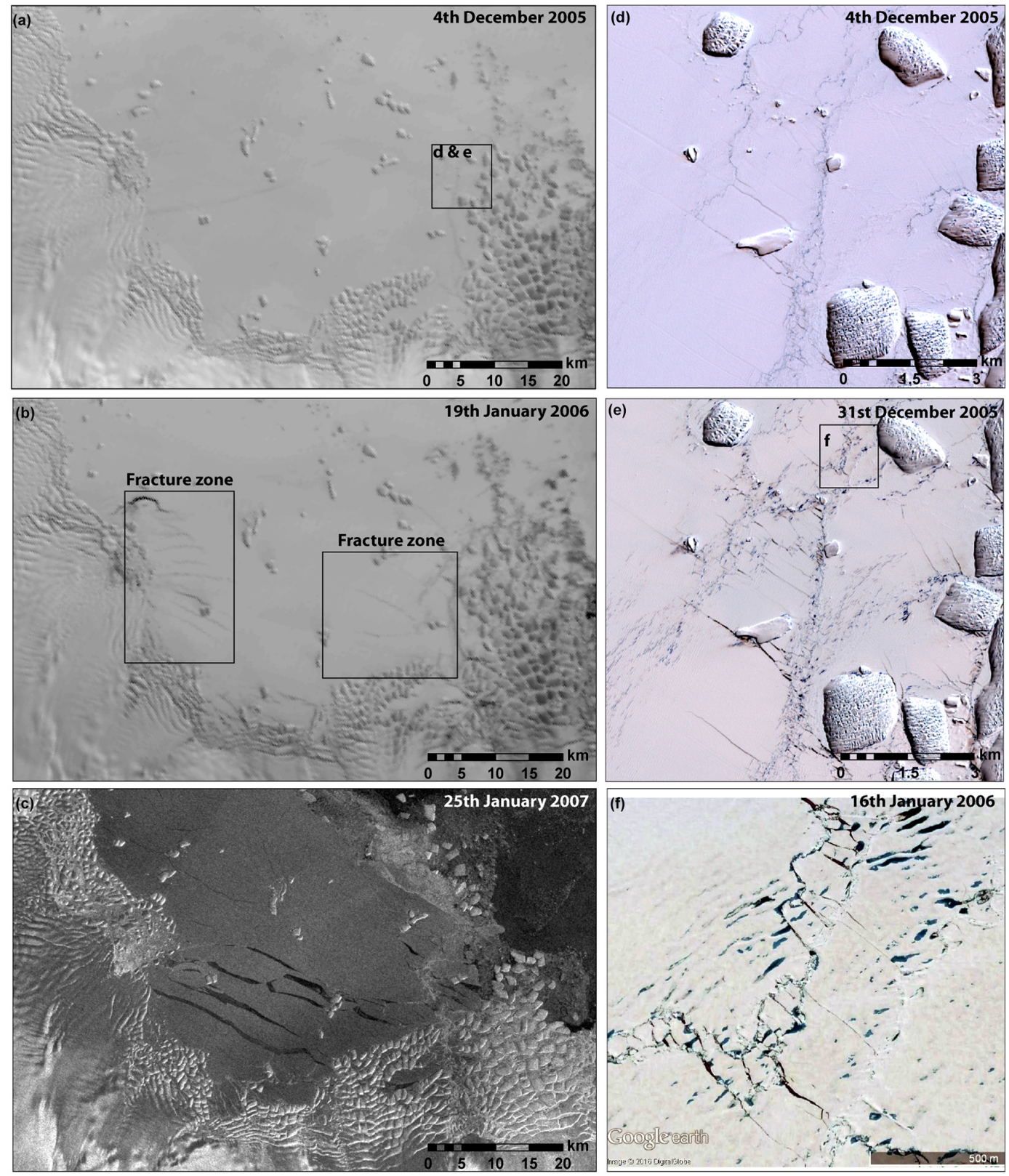

Figure 13. (a, b) MODIS imagery showing the development of fractures in the landfast sea ice between 4 December 2005 and 19 January 2006 (Scambos et al., 1996; http://dx.doi.org/10.7265/N5NC5Z4N). (c) The landfast sea ice ruptures along some of the same fractures which formed in December/January 2005/2006, eventually leading to complete break-up in January 2007. (d, e) ASTER imagery showing surface melt features and the development of smaller fracture between 4 and 31 December 2005. (f) High-resolution optical satellite imagery from 16 January 2006 showing sea ice fracturing and surface melt ponding. This image was obtained from Google Earth.

swell may have initiated the break-up of the already weakened multi-year sea ice in Porpoise Bay.

In contrast to January 2007, we find no link between atmospheric-circulation anomalies and the March 2016 sea ice break-up. In the months preceding the March 2016 breakup, wind and SST anomalies indicate conditions close to average conditions favouring sea ice stability (Fig. 9d, e, f). This suggests that another process was important in driv- ing the March 2016 sea ice break-up. A key difference between the 2007 and 2016 event is that the largest glacier in the bay, Holmes (West) Glacier, only calved in the 2016 event. Analysis of its calving cycle (Fig. 12) indicates that it calves at roughly the same position in each cycle and that its relative position in early 2016 suggests that calving was "overdue" (Fig. 12). This indicates that the calving cycle of Holmes (West) Glacier has not necessarily been driven by at- 


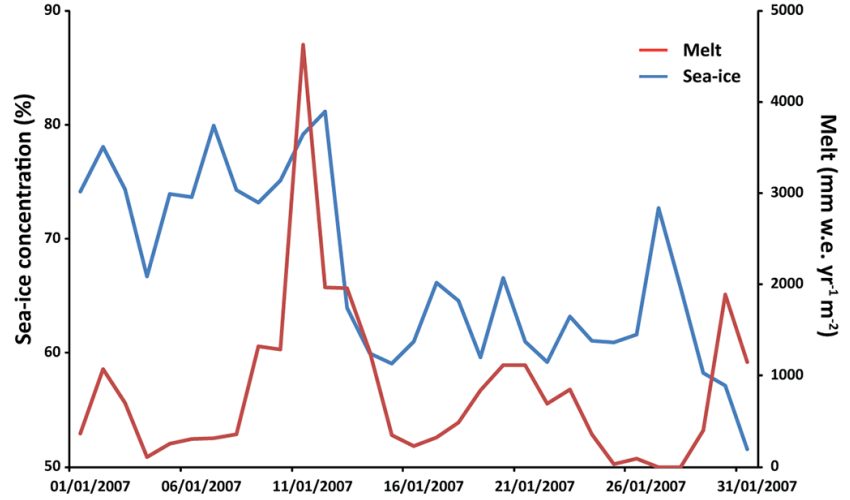

Figure 14. Daily sea ice concentrations and RACMO2.3 derived melt during January 2007 in Porpoise Bay. Sea ice concentrations start to decrease after the melt peak on 11 January.

mospheric circulation anomalies. Instead, we suggest that as Holmes (West) Glacier advances, it slowly pushes the multiyear sea ice attached to its terminus further towards the open ocean to the point where the sea ice attached to the glacier tongue becomes more unstable. This could be influenced by local bathymetry and oceanic circulation, but no observations are available. However, once the multi-year sea ice reaches an unstable state, break-up is still likely to be forced by a synoptic event. This is consistent with our observations, where ERA-Interim derived wind fields show the presence of a lowpressure system close to Porpoise Bay on the estimated date of sea ice break-up in March 2016 (Fig. 11b). Whilst we suggest that the March 2016 sea ice break-up and subsequent calving of Holmes (West) are currently part of a predictable cycle, we note that this could be vulnerable to change if any future changes in climate alter the persistence and/or strength of the multi-year sea ice, which is usually attached to the glacier terminus.

\section{Conclusions}

We identify two large near-simultaneous calving events in January 2007 and March 2016 which were driven by the break-up of the multi-year landfast sea ice which usually occupies the bay. This provides a previously unreported mechanism for the rapid disintegration of floating glacier tongues in East Antarctica, adding to the growing body of research linking glacier tongue stability to the mechanical coupling of landfast ice (e.g. Khazander et al., 2009; Massom et al., 2010). Our results suggest that multi-year sea ice break-ups in 2007 and 2016 in Porpoise Bay were driven by different mechanisms. We link the 2007 event to atmosphericcirculation anomalies in December 2005 weakening multiyear sea ice through a combination of surface melt and a change in wind direction, prior to its eventual break-up in 2007. This is in contrast to the March 2016 event, which we suggest is part of a longer-term cycle based on the terminus position of Holmes (West) Glacier that was able to advance and push sea ice out of the bay. The link between sea ice break-up and major calving of glacier tongues is especially important because it suggests that with predictions of future warming (DeConto and Pollard, 2016) multi-year landfast ice may become less persistent. Therefore, the glacier tongues which depend on landfast ice for stability may become less stable in the future. In a wider context, our results also highlight the complex nature of the mechanisms which drive glacier calving position in Antarctica. Whilst regional trends in terminus position can be driven by ocean-climatesea ice interaction (e.g. Miles et al., 2013, 2016), individual glaciers and individual calving events have the potential to respond differently to similar climatic forcing.

\section{Data availability}

Porpoise Bay terminus position shapefiles are available upon request, please contact the corresponding author. Envisat ASAR Wide Swath imagery is available from the European Space Agency. Landsat and ASTER imagery are available from Earth Explorer (https://earthexplorer.usgs. gov/). The Bootstrap sea ice concentration data used are available via the NSIDC website (http://dx.doi.org/10.5067/ J6JQLS9EJ5HU) (Comiso, 2014).

Competing interests. The authors declare that they have no conflict of interest.

Acknowledgements. We thank the ESA for providing Envisat ASAR WSM data (project ID: 16713) and Sentinel data. Landsat imagery was provided free of charge by the US Geological Survey Earth Resources Observation Science Centre. We thank M. van den Broeke for providing data and assisting with RACMO. B. W. J. Miles was funded by a Durham University Doctoral Scholarship program. S. S. R. Jamieson was supported by Natural Environment Research Council Fellowship NE/J018333/1. We would like to thank Allen Pope and Ted Scambos for reviewing the manuscript, along with the editor, Rob Bingham, for providing constructive comments which led to improvement of this manuscript.

Edited by: R. Bingham

Reviewed by: T. A. Scambos and one anonymous referee

\section{References}

Aitken, A. R. A., Roberts, J. L., van Ommen, T. D., Young, D. A., Golledge, N. R., Greenbaum, J. S., Blankenship, D. D., and Siegert, M. J.: Repeated large-scale retreat and advance of Totten Glacier indicated by inland bed erosion, Nature, 533, 385-389, doi:10.1038/nature17447, 2016. 
Amundson, J. M., Fahnestock, M., Truffer, M., Brown, J., Luthi, M. P., and Motyka, R. J.: Ice melange dynamics and implications for terminus stability, Jakobshavn Isbrae Greenland, J. Geophys. Res.-Earth, 115, F01005, doi:10.1029/2009jf001405, 2010.

Arntsen, A. E., Song, A. J., Perovich, D. K., and RichterMenge, J. A.: Observations of the summer breakup of an Arctic sea ice cover, Geophys. Res. Lett., 42, 8057-8063, doi:10.1002/2015GL065224, 2015.

Astrom, J. A., Vallot, D., Schafer, M., Welty, E. Z., O’Neel, S., Bartholomaus, T. C., Liu, Y., Riikila, T. I., Zwinger, T., Timonen, J., and Moore, J. C.: Termini of calving glaciers as self-organized critical systems, Nat. Geosci., 7, 874-878, doi:10.1038/NGEO2290, 2014.

Banwell, A. F., MacAyeal, D. R., and Sergienko, O. V.: Breakup of the Larsen B Ice Shelf triggered by chain reaction drainage of supraglacial lakes, Geophys. Res. Lett., 40, 5872-5876, doi:10.1002/2013GL057694, 2013.

Bassis, J. N. and Jacobs, S.: Diverse calving patterns linked to glacier geometry, Nat. Geosci., 6, 833-836, doi:10.1038/NGEO1887, 2013.

Benn, D. I., Warren, C. R., and Mottram, R. H.: Calving processes and the dynamics of calving glaciers, Earth-Sci. Rev., 82, 143 179, doi:10.1016/j.earscirev.2007.02.002, 2007.

Carr, J. R., Vieli, A., and Stokes, C.: Influence of sea ice decline, atmospheric warming, and glacier width on marine-terminating outlet glacier behavior in northwest Greenland at seasonal to interannual timescales, J. Geophys. Res.-Earth, 118, 1210-1226, doi:10.1002/Jgrf.20088, 2013.

Cassotto, R., Fahnestock, M., Amundson, J. M., Truffer, M., and Joughin, I.: Seasonal and interannual variations in ice melange and its impact on terminus stability, Jakobshavn Isbrae, Greenland, J. Glaciol., 61, 76-88, doi:10.3189/2015JoG13J235, 2015.

Chapuis, A. and Tetzlaff, T.: The variability of tidewater-glacier calving: origin of event-size and interval distributions, J. Glaciol., 60, 622-634, doi:10.3189/2014JoG13J215, 2014.

Comiso, J. C.: Bootstrap Sea Ice Concentrations from Nimbus-7 SMMR and DMSP SSM/I-SSMIS. Version 2, Boulder, Colorado USA, NASA National Snow and Ice Data Center Distributed Active Archive Center, 2014.

Cook, A. J., Fox, A. J., Vaughan, D. G., and Ferrigno, J. G.: Retreating Glacier Fronts on the Antarctic Peninsula over the Past HalfCentury, Science, 308, 541-544, doi:10.1126/science.1104235, 2005

Cook, C. P., Hill, D. J., van de Flierdt, T., Williams, T., Hemming, S. R., Dolan, A. M., Pierce, E. L., Escutia, C., Harwood, D., Cortese, G., and Gonzales, J. J.: Sea surface temperature control on the distribution of far-traveled Southern Ocean ice-rafted detritus during the Pliocene, Paleoceanography, 29, 533-548, doi:10.1002/2014pa002625, 2014

DeConto, R. M. and Pollard, D.: Contribution of Antarctica to past and future sea-level rise, Nature, 531, 591-597, doi:10.1038/nature17145, 2016.

Depoorter, M. A., Bamber, J. L., Griggs, J. A., Lenaerts, J. T. M., Ligtenberg, S. R. M., van den Broeke, M. R., and Moholdt, G.: Calving fluxes and basal melt rates of Antarctic ice shelves, Nature, 502, doi:10.1038/Nature12567, 2013.

Ehn, J. K., Mundy, C. J., Barber, D. G., Hop, H., Rossnagel, A., and Stewart, J.: Impact of horizontal spreading on light propagation in melt pond covered seasonal sea ice in the Canadian Arctic, J. Geophys. Res.-Oceans, 116, C00g02, doi:10.1029/2010jc006908, 2011.

Flocco, D., Feltham, D. L., Bailey, E., and Schroeder, D.: The refreezing of melt ponds on Arctic sea ice, J. Geophys. Res.Oceans, 120, 647-659, doi:10.1002/2014JC010140, 2015.

Fraser, A. D., Massom, R. A., Michael, K. J., Galton-Fenzi, B. K., and Lieser, J. L.: East Antarctic Landfast Sea Ice Distribution and Variability, 2000-08, J. Climate, 25, 1137-1156, doi:10.1175/Jcli-D-10-05032.1, 2012.

Frezzotti, M. and Polizzi, M.: 50 years of ice-front changes between the Adélie and Banzare Coasts, East Antarctica, Ann. Glaciol., 34, 235-240, doi:10.3189/172756402781817897, 2002.

Fürst, J. J., Durand, G., Gillet-Chaulet, F., Tavard, L., Rankl, M., Braun, M., and Gagliardini, O.: The safety band of Antarctic ice shelves. Nature Climate Change, 6, 479-481, 2016.

Greenbaum, J. S., Blankenship, D. D., Young, D. A., Richter, T. G., Roberts, J. L., Aitken, A. R. A., Legresy, B., Schroeder, D. M., Warner, R. C., van Ommen, T. D., and Siegert, M. J.: Ocean access to a cavity beneath Totten Glacier in East Antarctica, Nat. Geosci., 8, 294-298, doi:10.1038/NGEO2388, 2015.

Heil, P.: Atmospheric conditions and fast ice at Davis, East Antarctica: A case study, J. Geophys. Res.-Oceans, 111, C05009 doi:10.1029/2005jc002904, 2006.

Khazendar, A., Rignot, E., and Larour, E.: Roles of marine ice, rheology, and fracture in the flow and stability of the Brunt/Stancomb-Wills Ice Shelf, J. Geophys. Res.-Earth, 114, F04007 doi:10.1029/2008jf001124, 2009.

Kim, K., Jezek, K. C., and Liu, H.: Orthorectified image mosaic of Antarctica from 1963 Argon satellite photography: image processing and glaciological applications, Int. J. Remote Sens., 28, 5357-5373, 2007.

King, M. A., Bingham, R. J., Moore, P., Whitehouse, P. L., Bentley, M. J., and Milne, G. A.: Lower satellite-gravimetry estimates of Antarctic sea-level contribution, Nature, 491, 586-589, doi:10.1038/Nature11621, 2012.

Kingslake, J., Ng, F., and Sole, A.: Modelling channelized surface drainage of supraglacial lakes, J. Glaciol., 61, 185-199, 2015.

Landy, J., Ehn, J., Shields, M., and Barber, D.: Surface and melt pond evolution on landfast first-year sea ice in the Canadian Arctic Archipelago, J. Geophys. Res.-Oceans, 119, 3054-3075, doi:10.1002/2013JC009617, 2014.

Langhorne, P. J., Squire, V. A., Fox, C., and Haskell, T. G.: Lifetime estimation for a land-fast ice sheet subjected to ocean swell, Ann. Glaciol., 33, 333-338, doi:10.3189/172756401781818419, 2001.

Langlais, C. E., Rintoul, S. R., and Zika, J. D.: Sensitivity of Antarctic Circumpolar Current Transport and Eddy Activity to Wind Patterns in the Southern Ocean, J. Phys. Oceanogr., 45, 10511067, doi:10.1175/Jpo-D-14-0053.1, 2015.

Langley, E. S., Leeson, A. A., Stokes, C. R., and Jamieson, S. S. R.: Seasonal evolution of supraglacial lakes on an East Antarctic outlet glacier, Geophys. Res. Lett., 43, 8563-8571, doi:10.1002/2016GL069511, 2016

Lei, R. B., Li, Z. J., Cheng, B., Zhang, Z. H., and Heil, P.: Annual cycle of landfast sea ice in Prydz Bay, east Antarctica, J. Geophys. Res.-Oceans, 115, C02006 doi:10.1029/2008jc005223, 2010 . 
Liu, H. X. and Jezek, K. C.: A complete high-resolution coastline of antarctica extracted from orthorectified Radarsat SAR imagery, Photogramm Eng. Rem. S., 70, 605-616, 2004.

Mahoney, A., Eicken, H., Gaylord, A. G., and Shapiro, L.: Alaska landfast sea ice: Links with bathymetry and atmospheric circulation, J. Geophys. Res.-Oceans, 112, C02001, doi:10.1029/2006jc003559, 2007.

Marshall, G. J.: Trends in the southern annular mode from observations and reanalyses, J. Climate, 16, 4134-4143, doi:10.1175/1520-0442(2003)016<4134:Titsam>2.0.Co;2, 2003

Marshall, G. J.: Half-century seasonal relationships between the Southern Annular Mode and Antarctic temperatures, Int. J. Climatol., 27, 373-383, doi:10.1002/joc.1407, 2007.

Massom, R. A., Giles, A. B., Warner, R. C., Fricker, H. A., Legresy, B., Hyland, G., Lescarmontier, L., and Young, N.: External influences on the Mertz Glacier Tongue (East Antarctica) in the decade leading up to its calving in 2010, J. Geophys. Res.-Earth, 120, 490-506, doi:10.1002/2014JF003223, 2015.

McMillan, M., Shepherd, A., Sundal, A., Briggs, K., Muir, A., Ridout, A., Hogg, A., and Wingham, D.: Increased ice losses from Antarctica detected by CryoSat-2, Geophys. Res. Lett., 41, 3899-3905, doi:10.1002/2014g1060111, 2014.

Miles, B. W. J., Stokes, C. R., Vieli, A., and Cox, N. J.: Rapid, climate-driven changes in outlet glaciers on the Pacific coast of East Antarctica, Nature, 500, 563-566, doi:10.1038/Nature12382, 2013.

Miles, B. W. J., Stokes, C. R., and Jamieson, S. S. R.: Pan-icesheet glacier terminus change in East Antarctica reveals sensitivity of Wilkes Land to sea ice changes, Science Advances, 2, 5, doi:10.1126/sciadv.1501350, 2016.

Moon, T. and Joughin, I.: Changes in ice front position on Greenland's outlet glaciers from 1992 to 2007, J. Geophys. Res.-Earth, 113, F02022, doi:10.1029/2007jf000927, 2008.

Parkinson, C. L., Comiso, J. C., and Zwally, H. J.: Nimbus-5 ESMR Polar Gridded Sea Ice Concentrations, edited by: Meier, W. and Stroeve, J., Boulder, Colorado USA, National Snow and Ice Data Center. Digital media, updated 2004.

Petrich, C., Eicken, H., Polashenski, C. M., Sturm, M., Harbeck, J. P., Perovich, D. K., and Finnegan, D. C.: Snow dunes: A controlling factor of melt pond distribution on Arctic sea ice, J. Geophys. Res.-Oceans, 117, C09029, doi:10.1029/2012jc008192, 2012.

Pritchard, H. D., Arthern, R. J., Vaughan, D. G., and Edwards, L. A.: Extensive dynamic thinning on the margins of the Greenland and Antarctic ice sheets, Nature, 461, 971-975, doi:10.1038/nature08471, 2009.

Rignot, E., Casassa, G., Gogineni, P., Krabill, W., Rivera, A., and Thomas, R.: Accelerated ice discharge from the Antarctic Peninsula following the collapse of Larsen B ice shelf, Geophys. Res. Lett., 31, L18401, doi:10.1029/2004g1020697, 2004.

Rignot, E., Mouginot, J., and Scheuchl, B.: Ice Flow of the Antarctic Ice Sheet, Science, 333, 1427-1430, doi:10.1126/science.1208336, 2011.

Rignot, E., Jacobs, S., Mouginot, J., and Scheuchl, B.: IceShelf Melting Around Antarctica, Science, 341, 266-270, doi:10.1126/science.1235798, 2013.
Rott, H., Skvarca, P., and Nagler, T.: Rapid collapse of northern Larsen Ice Shelf, Antarctica, Science, 271, 788-792, doi:10.1126/science.271.5250.788, 1996.

Rott, H., Rack, W., Skvarca, P., and De Angelis, H.: Northern Larsen Ice Shelf, Antarctica: further retreat after collapse, Ann. Glaciol., 34, 277-282, doi:10.3189/172756402781817716, 2002.

Sasgen, I., Konrad, H., Ivins, E. R., Van den Broeke, M. R., Bamber, J. L., Martinec, Z., and Klemann, V.: Antarctic ice-mass balance 2003 to 2012: regional reanalysis of GRACE satellite gravimetry measurements with improved estimate of glacial-isostatic adjustment based on GPS uplift rates, The Cryosphere, 7, 1499-1512, doi:10.5194/tc-7-1499-2013, 2013.

Scambos, T., Bohlander, J., and Raup, B.: Images of Antarctic Ice Shelves. Boulder, Colorado USA, National Snow and ICe Data Center, doi:10.7265/N5NC5Z4N, 1996.

Scambos, T., Hulbe, C., and Fahnestock, M.: Climate-induced ice shelf disintegration in the Antarctic Peninsula, Antarct. Res. Ser., 79, 79-92, 2003.

Scambos, T., Fricker, H. A., Liu, C. C., Bohlander, J., Fastook, J., Sargent, A., Massom, R., and Wu, A. M.: Ice shelf disintegration by plate bending and hydro-fracture: Satellite observations and model results of the 2008 Wilkins ice shelf break-ups, Earth Planet Sc. Lett., 280, 51-60, doi:10.1016/j.eps1.2008.12.027, 2009.

Schroder, D., Feltham, D. L., Flocco, D., and Tsamados, M.: September Arctic sea ice minimum predicted by spring melt-pond fraction, Nature Climate Change, 4, 353-357, doi:10.1038/Nclimate2203, 2014.

Spreen, G., Kaleschke, L., and Heygster, G.: Sea ice remote sensing using AMSR-E 89-GHz channels, J. Geophys. Res.-Oceans, 113, C02s03, doi:10.1029/2005jc003384, 2008.

Sugimoto, F., Tamura, T., Shimoda, H., Uto, S., Simizu, D., Tateyama, K., Hoshino, S., Ozeki, T., Fukamachi, Y., Ushio, S., and Ohshima, K. I.: Interannual variability in sea ice thickness in the pack-ice zone off Lutzow-Holm Bay, East Antarctica, Polar Sci., 10, 43-51, doi:10.1016/j.polar.2015.10.003, 2016.

Todd, J. and Christoffersen, P.: Are seasonal calving dynamics forced by buttressing from ice mélange or undercutting by melting? Outcomes from full-Stokes simulations of Store Glacier, West Greenland, The Cryosphere, 8, 2353-2365, doi:10.5194/tc8-2353-2014, 2014.

Ushio, S.: Factors affecting fast-ice break-up frequency in Lutzow-Holm bay, Antarctica, Ann. Glaciol., 44, 177-182, doi:10.3189/172756406781811835, 2006.

van der Veen, C. J.: Calving glaciers, Prog. Phys. Geog., 26, 96122, doi:10.1191/0309133302pp327ra, 2002.

van Wessem, J. M., Reijmer, C. H., Morlighem, M., Mouginot, J., Rignot, E., Medley, B., Joughin, I., Wouters, B., Depoorter, M. A., Bamber, J. L., Lenaerts, J. T. M., van de Berg, W. J., van den Broeke, M. R., and van Meijgaard, E.: Improved representation of East Antarctic surface mass balance in a regional atmospheric climate model, J. Glaciol., 60, 761-770, 10.3189/2014JoG14J051, 2014.

Wuite, J., Rott, H., Hetzenecker, M., Floricioiu, D., De Rydt, J., Gudmundsson, G. H., Nagler, T., and Kern, M.: Evolution of surface velocities and ice discharge of Larsen B outlet glaciers from 1995 to 2013, The Cryosphere, 9, 957-969, doi:10.5194/tc9-957-2015, 2015. 
Yang, Y., Li, Z. J., Leppazranta, M., Cheng, B., Shi, L. Q., and Lei, R. B.: Modelling the thickness of landfast sea ice in Prydz Bay, East Antarctica, Antarct. Sci., 28, 59-70, doi:10.1017/S0954102015000449, 2016.
Young, D. A., Wright, A. P., Roberts, J. L., Warner, R. C., Young, N. W., Greenbaum, J. S., Schroeder, D. M., Holt, J. W., Sugden, D. E., Blankenship, D. D., van Ommen, T. D., and Siegert, M. J.: A dynamic early East Antarctic Ice Sheet suggested by ice-covered fjord landscapes, Nature, 474, 72-75, doi:10.1038/nature10114, 2011. 